\title{
BRINGING TRANSNATIONALISM (ONCE AGAIN) BACK IN - INSIGHTS FOR THE PARLIAMENTARY DIMENSION OF EUROPEAN FOREIGN POLICY
}

Daan Fonck

Kolja Raube 


\section{BRINGING TRANSNATIONALISM (ONCE AGAIN) BACK IN - INSIGHTS FOR THE PARLIAMENTARY DIMENSION OF EUROPEAN FOREIGN POLICY}

Daan Fonck

Leuven International and European Studies (LINES), University of Leuven

Kolja Raube

Center for European Studies and Leuven Centre for Global Governance Studies (GGS), University of Leuven 


\section{Table of Contents}

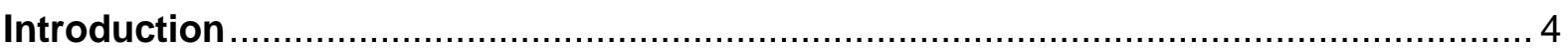

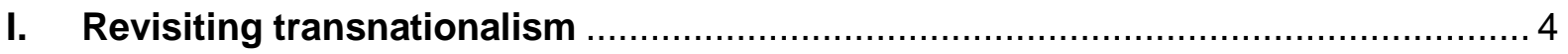

II. Trans-parliamentary blind spots in European Foreign Policy ........................... 6

III. Transnational Parliamentarism in EFP: What it is, what it does, and what it

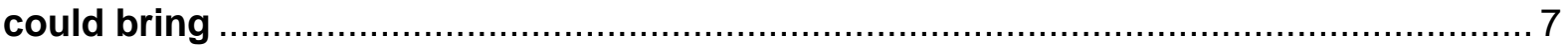

a. Transnationalism as a descriptive tool: making sense of the extra-parliamentary dimension of EFP.

b. Transnationalism as an explanatory tool: making sense of what parliamentary actors do ............. 9

c. Transnationalism as a normative tool: what transnational parliamentarism could bring ...............15

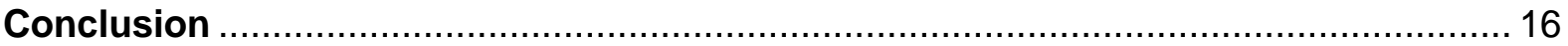




\section{Introduction}

Over the two last decades parliamentary actors have increasingly manifested transnational behaviour, taking the form of inter-parliamentary cooperation - i.e. the establishment of networks for inter-parliamentary exchange through conferences or permanent assemblies on the one hand, and parliamentary diplomacy - i.e. the practice of parliaments influencing an external actor or context, through bypassing executive foreign policies - on the other. Remarkably, however, the literature on European Foreign Policy (EFP) remains almost silent on the role or influence of such cross-border, or 'trans-parliamentary', activities.

Against this backdrop, we propose to study the parliamentary dimension in EFP through a transnational lens. Along the lines of DeBardeleben \& Hurrelman (2011), we argue that transnationalism is able to provide insights on the parliamentary dimension of EFP on three different aspects. First, it has the ability to serve as a descriptive tool that is able to provide an ontology of the transnational parliamentary field. Second, transnational perspectives allow us to understand the cross-border behavior and functions of parliamentary actors in European Foreign Policy. And finally, transnationalism brings forward the normative agenda of transnational parliamentarism, as it is engaged with democratising international politics through empowering societal actors.

This WP is structured as follows. First, the main tenets of transnationalism are introduced, after which we elaborate on the persisting 'trans-parliamentary blind spots' in the EFP literature. This allows us to propose a threefold application of transnationalist insights to help us elucidate the ontology, functions and normative promises of inter-parliamentary cooperation and parliamentary diplomacy.

\section{Revisiting transnationalism}

The concept of transnationalism lives many lives within the world of social sciences. It became most known from being introduced to International Relations theory by Nye and Keohane in the 1970s, by defining the term as 'the presence of at least one societal actor - meaning an actor who is neither an agent of a state nor of an international organization - in border crossing interactions' (Nye \& Keohane in Hurrelmann, 2011). Although the phenomenon of transnationalism was not a new one, the introduction of the concept helped to understand relations between states and societies beyond the governmental level. It forced researchers to rethink which factors determined governments to take action, considering the societal (complex) interdependence of states based on 'border crossing interactions', such as those in economic trade. Moreover, it opened a perspective on the role of NGOs and civil society organizations in international relations and norm-setting (Risse-Kappen, 1997). 
The concept has also been widely studied from sociological perspectives, where transnationalism is conceived as a process creating, redefining or sustaining social spaces. It has been coined as happening both "from below" and "from above". "[...] [T]ransnationalism from below is interested in the everyday behaviour and social worlds of individuals who themselves create transnational social spheres', whereas 'transnationalism from above means the intensification of international exchange relationships created by nation-states, international and supranational organizations, as well as internationally acting corporations, but also by international financial and product markets' (Mau 2010: 24-25).

Transgovernmentalist ${ }^{1}$ studies have focused on how (sub-)governmental units and sectors interacted across borders in global governance. For example, in A New World Order, Anne Marie Slaughter (2005) describes an ever more interdependent world as a network of transgovernmental relations, including the role of parliaments in networked globalism. Her analysis however concludes that parliaments still lack both the ability and interest to network with other parliaments in the world and essentially run behind the advanced governmental interplays that effectively shape global governance.

In the context of European Studies, transnationalism has played an especially prominent role in transactionalist, intergovernmentalist, neo-functionalist and supranationalist approaches to integration (Hurrelmann 2011). Transactionalist perspectives, introduced by Karl W. Deutsch $(\mathrm{X})$, saw transnational interactions beyond the nation-state (such as communication) as having impact on integration, while liberal intergovernmentalist focused on transnationally embedded national actors who would impact upon governmental decision-makers (Hurrelmann, 2011; see also Mau, 2010: 41). Finally, neo-Functionalists and supranationalists focus on how transnational society impacts on EU institutions to proceed with deeper integration (Fligstein and Stone Sweet, 2002: 1209). In the latter case, transnational lobbying has been identified as a key to understand a loyalty shift towards supranational institutions, such as the European Commission (Rosamond, 2000).

Overall, such European Studies perspectives have looked into how transnational forces may contribute to explaining European integration; i.e. where transnationalism forms an independent variable and where European integration is an outcome (cf. also Hurrelman and DeBardeleben, 2011). However, a theoretical approach to studying transnational actor participation in the very process of European Foreign Policy has been applied much more rarely. Thus far it has also been limited to the study of 'private' transnational civil society actors

\footnotetext{
${ }^{1}$ Falling under the original definition of transnationalism provided by Keohane and Nye (1971b).
} 
on the one hand (Joachim and Dembinski, 2011; Voltolini, 2016) or transgovernmental actors (e.g. Cross, 2011; Chelotti, 2013) on the other.

In this WP, we attempt to fill this gap by focusing on the trans-parliamentary dimension of EFP. In that way we broaden the scope to parliamentary actors as a type of hybrid, societalsubgovernmental, actor.

\section{Trans-parliamentary blind spots in European Foreign Policy}

Throughout the last decade, a debate on theorizing and analyzing EFP has gradually gained ground (Tonra and Christiansen, 2004; Carlsnaes et al., 2004; Jørgensen, 2015), driven by an expansion of the policy scope and the institutional capacity of the EU in foreign policy.

Notwithstanding these advances, thus far, transnational parliamentary processes remain notoriously absent from the debate (Raube, 2014), despite a simultaneous rise and expansion of inter-parliamentary networks, increased inter-parliamentary coordination and the rise of parliamentary diplomacy within and beyond the European Union (Crum and Fossum, 2009; Stavridis and Jančić, 2016). Why, then, are these so-called 'trans-parliamentary activities' missing from the analysis of EFP?

The current literature on EFP is characterized by fragmentation, mostly as a corollary of its splintered agency. With three sources of authority (i.e. the national, the intergovernmental, and the supranational) constituting EFP, three corresponding policy making regimes can be discerned, where each type 'attracts a different cluster of actors, is characterised by a different policy process, operates within a distinctive context and across a specific agenda, utilizes different sorts of policy instruments, and generates different outputs' (White, 2004: 55).

Corresponding to this fragmented literature, the study of parliamentary involvement in EFP has equally developed into separate study fields (see also Wagner, 2015). To begin with, considerable attention has been yielded to the study of national parliaments in national foreign and security policies (e.g. Peters and Wagner, 2011), to the study of national parliaments in the EU's ESDP/CSDP (e.g. Born et al., 2007), or the 'Europeanisation' of national parliaments in overseeing EU politics and policies (e.g. Raunio, 2009). Following the Lisbon Treaty, a socalled 'parliamentary turn' to the study of EU external relations could be noticed, giving rise to a whole range of studies on the European Parliament (EP) in EU foreign policy (for an overview, see Van Hecke and Wolfs, 2015). Simultaneously, literature on the international actorness and parliamentary diplomacy of the EP has burgeoned, focusing on the relations of the EP with non-EU parliaments, governments or I(N)GOs (e.g. Stavridis and Jančić, 2016). And finally, yet another strand of research has commenced with studying the proliferation and 
empowerment of IPIs, treating the EP as a kind of primus inter pares (e.g. Cofelice and Stavridis, 2014; Cutler, 2013).

Much more rarely, however, these different 'parliamentary fields' are studied in relation to one another, across levels or policy fields (exceptions include Herranz-Surrallés, 2014; Born et al., 2007; Wouters and Raube, 2016). This has led neglect of the cross-border links between the different parliamentary actors, which is problematic to the extent that the different policymaking regimes within EFP have become more and more interwoven over time, and are in fact, in constant interaction with each other (White, 2004). More generally, processes of European integration and the much wider process of globalization make that distinctions between domestic and foreign policy issues become ambiguous and therefore require 'parliamentarians to become international actors if they wish to defend interest of their local constituencies adequately' (Šabič, 2008: 85).

Granted, attention has been yielded to the rise of inter-parliamentary cooperation (Crum and Fossum, 2009; Crum and Fossum, 2013) or 'multilayered parliamentarism' (Jancic, 2014; Jancic, 2015) within and beyond the EU. Yet thus far, this debate remains limited to the study of interparliamentary cooperation within the EU, and is heavily embedded in discourses or theories on democracy and legitimacy. More reflection is required on describing the nature of cross-border parliamentary interaction, on exposing the driving forces constituting its agency, and on studying the normative merits such transparliamentary proliferation may bring forward.

\section{Transnational Parliamentarism in EFP: What it is, what it does, and what it could bring}

Having identified the 'trans-parliamentary blind spots' in the EFP literature, this section aims to demonstrate the relevance of applying a transnational approach to the study of parliamentary actors in the making of EFP. Along the lines of DeBardeleben \& Hurrelman (2011) (see also Wiener and Diez, 2009; Jørgensen, 2015) we argue that, as a framework for analysis, transnationalism can be invoked to provide insights on three different aspects.

First, it has the ability to serve as a descriptive tool, providing an ontology of the transnational parliamentary field in EFP. Second, transnational perspectives can serve the purpose of explaining the cross-border behaviour and functions of parliamentary actors. And finally, transnationalism brings forward a normative agenda as it is engaged with democratising international politics through empowering societal actors.

a. Transnationalism as a descriptive tool: making sense of the extra-parliamentary dimension of EFP 
Descriptive or interpretative theory provides the basic toolsets for analysis. It supplies the necessary concepts, definitions or classification schemes to capture the nature of the object of study, serving as the groundwork for further analysis (Wiener and Diez, 2009: 18; Jørgensen, 2015: 81). Before turning to explaining transnational parliamentary behaviour, this section therefore deals with the prerequisites, that is, to expound the main concepts and ideas that underpin a transnational understanding of the parliamentary dimension of EFP.

Defining parliaments as transnational actors: a behavioural approach

As argued hereinabove, the literature on transnationalism has almost exclusively focused on the behaviour of private or non-governmental actors possessing international agency. However, the inclusion of parliamentary actors as a type of transnational actor (TNA) is warranted for two main reasons. First, among the various typologies and definitions that the transnational literature has produced, there is strong agreement that clear-cut distinctions between either state and non-state, public and private, or governmental and nongovernmental actors, are not always mutually exclusive in reality (Agnew, 1994; Josselin and Wallace, 2001; Walker, 1992). Instead, a more complex and hybrid reality lurks beneath such simplified unitary actor depictions, one in which actors often display several typical characteristics simultaneously. This also appears to be the case for parliamentary actors which operate in between a purely 'private' sphere and entirely 'public' domain.

Second, in line with this argument, Nye and Keohane have contended that transnational behaviour is essentially manifested when domestic actors operate (semi-)autonomously across state boundaries, while 'not [being] controlled by the central foreign policy organs of governments' (Nye and Keohane, 1971b: 331). The status of TNAs is therefore to be derived from behavioural roles and not from the formal position the actor occupies in a binary governmental vs. non-governmental categorization scheme (Nye and Keohane, 1971a: 733).

In short, following Nye and Keohane's 'behavioural approach', parliamentary actors can be conceptualized as TNAs when they (1) operate cross-border, (2) while bypassing a polity's formal executive agents, (3) and instead act directly towards their peers or other foreign political actors of another polity. ${ }^{2}$

\footnotetext{
2 Similar approaches to transnationalism can be found in the 'paradiplomacy' literature, studying the involvement of non-central governments in international affairs (e.g. Soldatos, 1993; Duchacek, 1990).
} 
Having defined the subject of action (i.e. how parliamentary actors qualify as TNAs), a conception of the object of action, transnational parliamentarism, can hence be introduced as an overarching term to capture cross-border parliamentary activity.

We are not the first ones to propose the concept of 'transnational parliamentarism', as Davor Jancic has employed the term as a 'cognitive framework (...) encompassing all international parliamentary activities under one umbrella' (Jancic, 2015: 114). Further building on Jancic' umbrella-term, we define transnational parliamentarism more concretely as the investment of political capital of a parliamentary actor towards an actor of a foreign polity, while not being controlled by its domestic executive organs.

First, using the criterion of 'domestic' vs. 'foreign' polities, transnational parliamentary behaviour is thus to be discerned from mere domestic activities. In other words, parliamentary actors that invest political capital (through controlling, sanctioning, rulemaking, etc.) vis-à-vis their 'own' executive in their conduct of foreign policy are considered to pursue 'domestic' parliamentary functions. As soon as these actors invest political capital beyond that domestic sphere, however, such agency becomes bestowed with a transnational quality.

Second, the definition maintains a broad definition of parliamentary actors. It deliberately leaves open the question whether the actor is either a regional, national, or supranational parliament, or any other international parliamentary institution (IPI), such as a conference or an assembly associated with an international organization. In other words, the idea of transnational parliamentarism is not only characterized by the movement of (in)tangible items across state or national boundaries (while bypassing governmental agents), but rather across levels of governance or 'polity' boundaries, therefore opening itself for being applied at different levels of analysis (sub-national, national, regional, global).

\section{b. Transnationalism as an explanatory tool: making sense of what parliamentary actors do}

As an explanatory approach, transnationalist perspectives may contribute to answering the question why, how or when parliamentarians are inclined to act beyond their own domestic political spheres. When scanning the literature with regard to the why, how and when of transnational actor participation in global governance or foreign policy processes, three observations could respectively be made in that regard. 
First, as an accepted principle, transnational avenues of action are opted for when domestic avenues to policy influence are constrained or result in limited impact (Risse-Kappen, 1997; Keck and Sikkink, 1999). Instead, it may be more effective to bypass executive foreign policy organs and establish cross-border relations with foreign actors in order to generate impact on both domestic and foreign governments.

For parliamentary actors, this in other words implies that when the domestic mechanisms for steering and controlling foreign policy are considered unsatisfactory, transnational strategies could be used as an additional pathway to influence. Within the policy domain of European foreign and security policy, the potential for transnational parliamentary interaction is promising in this regard. This predominantly intergovernmental policy area is characterized by strong executive prerogatives on both national and EU-levels, making it particularly resilient against a strong involvement of both the national parliaments and the European Parliament within their respective polities (see also Wagner, 2015: 366).

Second, the type of activities that are performed are essentially related to the type of actor at stake, since, obviously, 'different transnational actors have profoundly divergent purposes and goals' (Keck and Sikkink, 1999: 99). The functions performed by transnational parliamentarism are in other words inextricably linked to the intrinsic nature and the constitutional (or treaty-based) tasks of parliamentary actors such as debating, scrutinizing, legislating, and seeking accountability and control.

Finally, addressing the 'when'-question, the literature on transnational actor participation in global governance or foreign policy processes, tends to situate (implicitly or explicitly) the 'functions' of TNAs within different stages of the policy cycle, ranging from the policy formulation phase, to decision-making or implementation stages. Tallberg and Jönsson (2010) for example identify three functions of 'norm development or agenda-setting', 'policy implementation', and 'rule enforcement', while Abbott and Snidal (2009) propose five main tasks again corresponding to different policy stages: agenda-setting, negotiating, implementation, monitoring and enforcement (for similar approaches see Reinalda, 2001: 24; Risse-Kappen, 1997; Keck and Sikkink, 1999).

Following from this, we propose that transnational parliamentarism within EFP is manifested as a method for pursing one of the following four main functions: agenda-setting, decisionmaking, governmental scrutiny, and diplomacy. 
Agenda-setting 'requires an ability to capture public attention, frame issues in politically powerful ways, gather and disseminate information, and formulate appropriate ways to proceed' (Abbott and Snidal, 2009: 21). It is one of the most straightforward functions of interparliamentary cooperation, through generating public debate and deliberation (Eriksen and Fossum, 2000; Lord, 2013; Crum and Fossum, 2009). By the very act of publicly debating issues, speech acts are performed, issues are framed and made salient, picked up by other actors; thus the more likely they will be put on the agenda of governmental agents.

The agenda setting of transnational parliamentary fora is mostly performed informally through the persuasion of executive actors, and indirectly in the sense that participating parliaments 'take home' deliberations and set the agenda respectively in their 'domestic' settings.

However, agenda-setting may also be performed directly, through formulating recommendations towards the governmental agents in charge of the international cooperation framework at stake. This happens for example through the adoption of resolutions or statements the aftermath of meetings of transparliamentary networks or by submitting recommendations to ministerial levels, with the latter being obliged to report on their followup.

Finally, parliamentary actors may also adopt agenda-setting strategies similar to those of advocacy groups by using methods of international issue framing (Keck and Sikkink, 1999). A prominent example in this respect is 'Parliamentarians for Global Action', a non-profit international grouping of parliamentarians who 'advocate for human rights and the rule of law, democracy, human security, non-discrimination, and gender equality'3. In the same vein, many issue-based parliamentary networks are active which campaign or raise attention to specific causes, conflicts, or injustices (Jancic, 2015). The annual Sakharov Prize Prize for freedom of thought, awarded by the EP, intended to honour and empower individuals or organisations that have shown an exceptional dedication towards the fight for human rights and the freedom of thought, is yet another example of agenda-setting through advocacy.

Transnational parliamentarism as a means for decision-making

In rare examples, transparliamentary organs have been given the competence to make decisions. This decision-making capacity could range from the power to propose draft legislative acts which are then submitted to a ministerial level, to a competence of consent

${ }^{3}$ http://www.pgaction.org/about/overview.html 
with decisions proposed by the executive level, to the mere right to be consulted before a decision is taken.

The most advanced transnational parliamentary cooperation framework is without any doubt the European Parliament itself, which in essence is a transnationally organized assembly. The EP is a key decision-making IPI within the European Union, with around $80 \%$ of EU legislative acts being adopted by the ordinary legislative procedure, granting co-decision powers to the EP. Beyond Europe, other transnational parliaments with decision-making powers include the CEMAC Community Parliament or the 'Union Economique et Monétaire Ouest Africaine' IPI.

In more rare cases IPIs are even granted the right to propose legislative acts, such as the Council of Europe's Parliamentary Assembly or the Inter-Parliamentary Assembly of the Commonwealth of Independent States (Petrova and Raube, 2015)

Transnational parliamentarism as a means for scrutiny

A third key activity often pursued by TNAs is that of monitoring governmental policies and enforcing compliance with declared engagements, therefore corresponding to the parliamentary function of scrutinising the executive. Transnational parliamentary scrutiny takes place in two different ways: indirectly (domestic scrutiny) and directly (international scrutiny).

Within a multi-level policy like European foreign and security policy, decisions are increasingly taken by 'bringing various policy tools together from various dimensions of security, trade, development and human rights', having important repercussions for parliaments' ability to scrutinize and control such decisions (Wouters and Raube, 2016: 234). In such context, transnational parliamentarism provides opportunities for improving scrutiny, hence better control, over the executive.

Engaging with peers from other parliaments, or with other foreign actors such as executive actors or non-governmental organisations, can serve as a means to overcome information asymmetries that exist in between parliament and government, and especially persist in the executive-led international decision-making (Zürn, 2004). Put differently, transnational parliamentarism here serves a feedback function for domestic activities of parliamentary scrutiny and control.

Several authors have indeed situated activities of transnational parliamentarism within such logic, particularly when debating the purpose or merits of inter-parliamentary cooperation (IPC) within the European Union. According to Crum and Fossum (2013), IPC within the EU 
is to be understood as an answer to the erosion of parliamentary control through the processes of European integration (and internationalisation by extension). The authors argue that parliaments have sought to rectify their position as 'outsiders' by means of setting up networks of inter-parliamentary cooperation in order to become better involved in international decisionmaking. Similarly, Raunio (2009: 322) sees IPC in EFP as a networking method bringing added value to the work of national parliaments: through sharing information, identifying common problems and exchanging best practices, MPs are able to better control and scrutinize their home governments.

Aside from the 'return' it might bring towards domestic scrutiny, trans-parliamentary exchange also creates potential for controlling and overseeing the actions of intergovernmental organisations to which the home governments are members of. In a voluminous study on the legal and political status of IPIs worldwide, Claudia Kissling (2011) drew as one of the main conclusions 'that IPIs are increasingly equipped with competences and functions that help them to fulfil genuine parliamentary oversight functions, although to a limited degree and regionally rather than globally. They can thus contribute to overcoming the existing democracy deficit at both regional and global levels' (2011: 9).

Similarly, for Crum and Fossum, IPC cannot exclusively be understood as serving as a means for national parliaments to compensate for the lack of information they have about their government's behaviour in international decision-making (Crum and Fossum, 2013: 2-3). Introducing the idea of a multilevel parliamentary field, they see parliamentary institutions as operating with, instead of next to, each other, together providing collective scrutiny for overarching governmental structures and decision-making.

In short, apart from providing a 'downward' feedback function for national parliaments (indirect scrutiny), IPC could de facto also provides a platform from which 'upward' parliamentary control and scrutiny could be exercised, contributing to the parliamentarisation of overarching government/governance-structures.

\section{Transnational parliamentarism as a means for diplomacy}

Finally, another step further in the policy cycle stage comes the actual participation of TNAs in the implementation or execution of foreign policy, i.e. diplomacy.

Throughout the last decade, a proliferation of accounts on non-state actor diplomacy can be witnessed which all demonstrate that 'diplomacy is no longer axiomatically linked to the state' (Murray, 2008: 25-26). In this sense, the recent scholarship on parliamentary diplomacy (Weisglas and de Boer, 2007; Stavridis and Jančić, 2016) could be inscribed into this new 
wave of studies, which examines how these 'new' non-state actors are able to shape policy outcomes and state interests (Hocking, 2011: 534; Sending et al., 2011).

A crucial question in that regard is whether parliamentary diplomats assist with implementing pre-defined foreign policy goals of their governments, or, rather, whether they pursue their own interests, regardless of what governmental actors desire.

A first option is that transnational parliamentary diplomacy is pursued in strong coordination with executive foreign policy. Nye and Keohane have suggested that states might have to rely on TNAs, in their execution of foreign policy as they might be dependent on some of the resources (services, information, legitimacy, ...) they can provide (Nye and Keohane, 1971b: 339). Parliaments on the other, evidently, also profit from these opportunities since they are given visibility and - to varying degrees - decision-making powers in the determination of foreign policies.

Examples of mutual alliances between governmental and transnational parliamentary activities in diplomacy are manifold. It is a well-known fact that at times of strained intergovernmental relations, parliamentary mediation, trust-building and reconciliation exercises are often employed to stimulate a 'thaw' in relations (Beetham, 2006). Interestingly, also the EP has recently been investing in its institutional capacity to deal with conflict prevention and resolution, through the creation of the 'European Parliament Mediation Support' (EPMS) service, which is exactly focused on strengthening the parliamentary capacity in transnational peace-mediation efforts and 'silent diplomacy'.

Jancic (2015) has drawn attention to an important (yet often unexploited) role for parliamentarians in either preventing or mediating the friction caused by legislation with extraterritorial bearing. Biedenkopf (2015) has demonstrated that, as veto-players for ratifying international agreements, parliamentarians' presence at international conferences might proof to be valuable in order to exchange with peers from other countries in order to draw red lines, to share their concerns, or to stimulate trust.

Parliamentary diplomacy might also be much more of an independent undertaking and therefore potentially complicate governmental foreign policy. As Kegley and Wittkopf (1993: 204) have put it, some TNAs 'are so powerful that they are able to pursue their interests outside the direct control of states, while at the same time sometimes involving governments in particular problems as a result of their activities'.

Some sporadic evidence of such competitive parliamentary diplomacy can be found in the case of the EP's Cox and Kwasnieski mission. Similarly, Redei (2015) has demonstrated how the EP is able to unilaterally set diplomatic precedents which have repercussions for the other 
EU institutional actors. The strategy through which the EP operates in these examples, is focused on creating precedents, both rhetorically (e.g. resolutions and statements oriented at foreign audiences) as well as on the ground (through visits of parliamentary delegations). In so doing, parliamentary actors attempt to entrap governmental actors, by altering their degree of freedom in the making of foreign policy decisions.

\section{c. Transnationalism as a normative tool: what transnational parliamentarism could bring}

As argued by Hurrelmann (2011), transnationalism can have impact on the democratic functioning of European governance. Transnational activities can in fact add to the deliberative exchange of arguments in transnational public spheres, a precondition for European democracy in the Habermasian sense.

According to Sjursen, democratic European foreign policy should fulfill a minimum of democratic legitimacy (2011: 1079). This minimum requirement is related to the principles of autonomy and accountability, that is 'the ability of those affected by laws should also to be their authors' and 'whether those who decide can be held responsible for their decisions' (Sjursen, 2011: 1080). Sjursen therefore argues such a minimum requirement of democratic legitimacy either needs to be fulfilled on the level of EU Member States (and potentially through the involvement of national parliaments) if the policy remains one of intergovernmental cooperation. In case of a supranational move (an uploading of competences to the EU), however, the legitimacy of the policy needs to be reflected, and mechanisms would need to be provided which would potentially empower the European Parliament.

However, transnational interparliamentary cooperation (IPC) can be seen as a means of interaction between parliaments - a third way of parliamentary activities with regards to democratic legitimacy in EFP. According to Crum and Fossum, 'the EU's Parliamentary Field contributes to the exercise of oversight over, and the conferral of democratic legitimacy on decision making in the multilevel constellation that makes up the EU' (Crum and Fossum 2009:264). The latter view entails cooperation between national parliaments and the EP in settings that brings representatives of European and national constituencies together. In the context of the IPC CFSP/CSDP for example (Wouters and Raube 2012, 2016), socialization amongst parliamentarians can lead to the exchange of information and the common understanding of parliamentarians, not to perceive their interactions as a 'battle field' (HerranzSurrallés, 2014), but a common parliamentary field in which accountability needs to be exercised on the European, national and transnational level of governance (Crum and Fossum 2009). 
Transnationalism can also be seen as a normative tool for transnational identity-building beyond democratic accountability (see Petrova and Raube 2016). In this vein, transnational cooperation across borders is a normative pre-requisite for trust- and community-building complementary to already existing identity-frames of the involved actors. In other words, transnationalism provides basic structures for actor socialization which can develop meaningful impact on democratic accountability and actor compliance. Transnational parliamentary cooperation, or diplomacy, should in this context be conceived not only as a structure for socialisation of parliamentarians across borders, but as an additional channel of norm diffusion (for example, see Petrova and Raube 2016). From this perspective, IPIs are not just transnational phenomena of parliamentary cooperation, but necessary structures to influence domestic contexts, change and compliance with European norms. Similarly, and according to the democratic peace theory, international norms like peace will be underlined by the ongoing interactions and structures of democratic parliaments and their transnational cooperation (Wagner, 2010), both in the context of parliamentary cooperation and diplomacy.

\section{Conclusion}

In this WP we have argued that transnationalism has the ability to serve as a descriptive tool that is able to provide an ontology of the transnational parliamentary field, and secondly, that transnational perspectives allow us to understand the cross-border behavior and functions of parliamentary actors in European Foreign Policy. We also argued that transnationalism brings forward the normative agenda of transnational parliamentarism, as it is engaged with democratising international politics through empowering societal actors. All together transnationalism is a tool for all three different purposes to study parliamentary action in and outside the European Union, be it inter-parliamentary cooperation or parliamentary diplomacy.

\section{References}

Abbott KW and Snidal D. (2009) The Governance Triangle: Regulatory Standards Institutions and The Shadow of the State. In: Mattli W and Woods N (eds) The Politics of Global Regulation. New Jersey: Princeton University Press, 44-88.

Agnew J. (1994) The Territorial Trap: The Geographical Assumptions of International Relations Theory. Review of International Political Economy 1: 53-80.

Beetham D. (2006) Parliament and democracy in the Twenty-first Century, Geneva: InterParliamentary Union/SRO-Kundig.

Biedenkopf K. (2015) The European Parliament in EU external climate governance. In: Stavridis S and Irrera D (eds) The European Parliament and its International Relations. Abingdon: Routledge.

Born H, Dowling A, Fuior T, et al. (2007) Parliamentary oversight of civilian and military ESDP missions: the European and national levels. Brussels: European Parliament. 
Carlsnaes W, Sjursen H and White B. (2004) Contemporary European Foreign Policy. London: Sage.

Chelotti N. (2013) Analysing the Links between National Capitals and Brussels in EU Foreign Policy. West European Politics 36: 1052-1072.

Cofelice A and Stavridis S. (2014) The European Parliament as an International Parliamentary Institution (IPI). European Foreign Affairs Review 19: 145-178.

Cross MaKD. (2011) Security Integration in Europe: How Knowledge-based Networks Are Transforming the European Union Michigan: Michigan University Press.

Crum B and Fossum JE. (2009) The Multilevel Parliamentary Field: a framework for theorizing representative democracy in the EU. European Political Science Review 1: 249-271.

Crum B and Fossum JE. (2013) practices of interparliamentary coordination in international politics: the European Union and beyond. Colchester: ECPR Press.

Cutler RM. (2013) International Parliamentary Institutions as Organizations. Journal of International Organizations Studies 4.

Eriksen EO and Fossum JE. (2000) Democracy in the European Union -Integration Through Deliberation? London: Routledge.

Fligstein N and Stone Sweet A. (2002) Constructing Polities and Markets: An Institutionalist Account of European Integration. American Journal of Sociology 107: 1206-1243.

Herranz-Surrallés A. (2014) The EU's Multilevel Parliamentary (Battle)Field: Interparliamentary Cooperation and Conflict in Foreign and Security Policy. West European Politics 37: 957-975.

Hocking B. (2011) Non-State Actors and the Transformation of Diplomacy. In: Reinalda B (ed) The Ashgate Research Companion to Non-State Actors. Surrey: Ashgate, 225236.

Hurrelmann A. (2011) Transnationalism and the Theory of European Integration: Political Science Perspectives. In: DeBardeleben J and Hurrelman A (eds) Transnational Europe: Promise, Paradox, Limits. Basingstoke: Palgrave Macmillan.

Jancic D. (2014) Multilayered International Parliamentarism: The Case of EU-Brazil Relations. LSE Law, Society and Economy Working Papers. London: LSE.

Jancic D. (2015) Transnational Parliamentarism and Global Governance: The New Practice of Democracy. In: Fahey E (ed) The Actors of Postnational Rulemaking: Contemporary Challenges of European and International Law. London: Routledge.

Joachim J and Dembinski M. (2011) A contradiction in terms? NGOs, democracy, and European foreign and security policy. Journal of European Public Policy 18: 11511168.

Jørgensen KE. (2015) Introduction: Theorising European Foreign Policy. In: Jørgensen KE, Aarstad AK, Drieskens E, et al. (eds) The SAGE Handbook of European Foreign Policy. London: Sage.

Josselin D and Wallace W. (2001) Non-state Actors in World Politics: a Framework. In: Josselin D and Wallace W (eds) Non-state Actors in World Politics. Hampshire: Palgrave Macmillan.

Keck ME and Sikkink K. (1999) Transnational advocacy networks in international and regional politics. International Social Science Journal 51: 89-101.

Kegley CW and Wittkopf ER. (1993) World Politics: Trend and Transformation, Hampshire: Macmillan Press.

Kissling C. (2011) The Legal and Political Status of International Parliamentary Institutions, Berlin: Committee for a Democratic U.N.

Lord C. (2013) The European Union: Parliamentary Wasteland or Parliamentary Field? In: Crum B and Fossum JE (eds) Practices of Inter-parliamentary Coordination in International Politics: The European Union and Beyond. Colchester: ECPR Press.

Mau S. (2010) Social Transnationalism. Lifeworlds beyond the nation-state, London: Routledge.

Murray S. (2008) Consolidating the Gains Made in Diplomacy Studies: A Taxonomy. International Studies Perspectives 9: 22-39. 
Nye JS and Keohane RO. (1971a) Transnational Relations and World Politics: A Conclusion. International Organization 25: 721-748.

Nye JS and Keohane RO. (1971b) Transnational Relations and World Politics: An Introduction. International Organization 25: 329-349.

Peters D and Wagner W. (2011) Between Military Efficiency and Democratic Legitimacy: Mapping Parliamentary War Powers in Contemporary Democracies, 1989-2004. Parliamentary Affairs 64: 175-192.

Petrova I and Raube K. (2015) Comparing multilateral parliamentary cooperation in the European borderlands. PADEMIA Workshop 'The European Parliament in the Contemporary World'. Ljubljana.

Raube K. (2014) Parliamentarization approaches: parliamentary control in EU foreign policy. In: Wilga M and Karolewski IP (eds) New Approaches to EU Foreign Policy. Oxon \& New York: Routledge.

Raunio T. (2009) National Parliaments and European Integration: What We Know and Agenda for Future Research. The Journal of Legislative Studies 15: 317-334.

Redei L. (2015) The European Parliament as a diplomatic precedent setter: the case of parliamentary relations with Kosovo. In: Stavridis S and Irrera D (eds) The European Parliament and its International Relations. Abingdon: Routledge.

Reinalda B. (2001) Private in Form, Public in Purpose: NGOs in International Relations Theory. In: Arts B, Noortmann M and Reinalda B (eds) Non-State Actors in International Relations. Aldershot: Ashgate Publishing Limited.

Risse-Kappen T. (1997) Bringing Transnational Relations Back in. Non-State Actors, Dometic Structures and International Institutions, Cambridge: Cambridge University Press.

Rosamond B. (2000) Theories of European Integration, Basingstoke: Palgrave Macmillan.

Šabič Z. (2008) Democracy Across Borders: Parliamentarians and International Public Spheres. Javnost - The Public 15: 75-88.

Sending OJ, Pouliot V and Neumann IB. (2011) The Future of Diplomacy: Changing Practices, Evolving Relationships. International Journal: Canada's Journal of Global Policy Analysis 66: 527-542.

Sjursen H. (2011) Not so intergovernmental after all? On democracy and integration in European Foreign and Security Policy. Journal of European Public Policy 18: 10781095.

Slaughter A-M. (2005) A New World Order, Princeton and Oxford: Princeton University Press.

Stavridis S and Jančić D. (2016) Introduction The Rise of Parliamentary Diplomacy in International Politics. The Hague Journal of Diplomacy 11: 105-120.

Tallberg J and Jönsson C. (2010) Transnational Actor Participation in International Institutions: Where, Why, and with What Consequences? In: Tallberg J and Jönsson C (eds) Transnational Actors in Global Governance. Patterns, Explanations and Implications. Hampshire: Palgrave Macmillan.

Tonra B and Christiansen T. (2004) Rethinking European Union Foreign Policy. Manchester: Manchester University Press.

Van Hecke S and Wolfs W. (2015) The European Parliament and European Foreign Policy. In: Jørgensen KE, Aarstad AK, Drieskens E, et al. (eds) The Sage Handbook of European Foreign Policy. London: Sage.

Voltolini B. (2016) Lobbying in EU foreign policy-making: the case of the Israeli-Palestinian conflict, Abingdon: Routledge.

Wagner W. (2010) Die demokratische Kontrolle internationalisierter Sicherheitspolitik (Weltpolitik im 21. Jahrhundert), Baden-Baden: Nomos.

Wagner W. (2015) National Parliaments. In: Jørgensen KE, Aarstad AK, Drieskens E, et al. (eds) The SAGE Handbook of European Foreign Policy. London: Sage.

Walker RBJ. (1992) Inside/Outside: International Relations as Political Theory, Cambridge: Cambridge University Press. 
Weisglas FF and de Boer G. (2007) Parliamentary Diplomacy. The Hague Journal of Diplomacy 2: 93-99.

White B. (2004) Foreign policy analysis and European foreign policy. In: Tonra B and Christiansen T (eds) Rethinking European Foreign Policy. Manchester: Manchester Universty Press.

Wiener A and Diez T. (2009) European Integration Theory. 2 ed. Oxford: Oxford University Press, 346.

Wouters $\mathrm{J}$ and Raube K. (2016) The many facets of parliamentary involvement and interaction in EU external relations. In: Lupo N and Fasone $\mathrm{C}$ (eds) Interparliamentary Cooperation in the Composite European Constitution. Oxford: Hart.

Zürn M. (2004) Global Governance and Legitimacy Problems. Government and Opposition 39: $260-287$. 